\title{
Unilateral erythaema nodosum: atypical presentation in paediatrics
}

\author{
Francisca Calheiros-Trigo, Sofia Martins
}

Department of Pediatrics, Hospital de Braga, Braga, Portugal

\section{Correspondence to} Dr Francisca Calheiros-Trigo, trigo.francisca@gmail.com

Accepted 10 November 2017

\section{CrossMark}

To cite: Calheiros-Trigo $F$, Martins S. BMJ Case Rep Published Online First: [please include Day Month Year]. doi:10.1136/bcr-2017222441

\section{DESCRIPTION}

A previously healthy 12 -year-old boy was observed in the emergency department due to pain and erythaema in the left shin for the past 2 weeks. He was discharged with flucloxacilin for cellulitis. One week later, he returned with oedema and erythaema of the left shin, with palpable nodules and purple discolouration (figure 1). The right leg was normal. Oropharyngeal hyperaemia was observed.

Complementary study revealed erythrocyte sedimentation rate of $12 \mathrm{~mm} /$ hour and antistreptolysin O titre was $985 \mathrm{UI} / \mathrm{mL}$ (normal range $0-408 \mathrm{UI} / \mathrm{mL}$ ). $\mathrm{C}$ reactive protein was $<2.90 \mathrm{mg} / \mathrm{dL}$; autoimmunity study, infectious serologies (hepatitis B virus and Epstein-Barr virus, EBV, Mycoplasma pneumoniae and Salmonella spp.) rapid strep test and Mantoux test were negative. Ultrasound showed subcutaneous oedema. Biopsy revealed septal panniculitis, compatible with erythaema nodosum (figure 2). $\mathrm{He}$ was discharged.

Four weeks later, there was resolution of nodules and oedema of left shin, which showed only minor discolouration, without atrophy or scarring (figure 3).

Erythaema nodosum is the most common presentation of panniculitis. ${ }^{12}$ This disease is rare among children, and its peak incidence occurs in the third decade. ${ }^{1-3}$ We found no descriptions of unilateral erythaema nodosum in children. Different stimuli cause inflammation of subcutaneous fat. ${ }^{1-3}$ Usually, no underlying

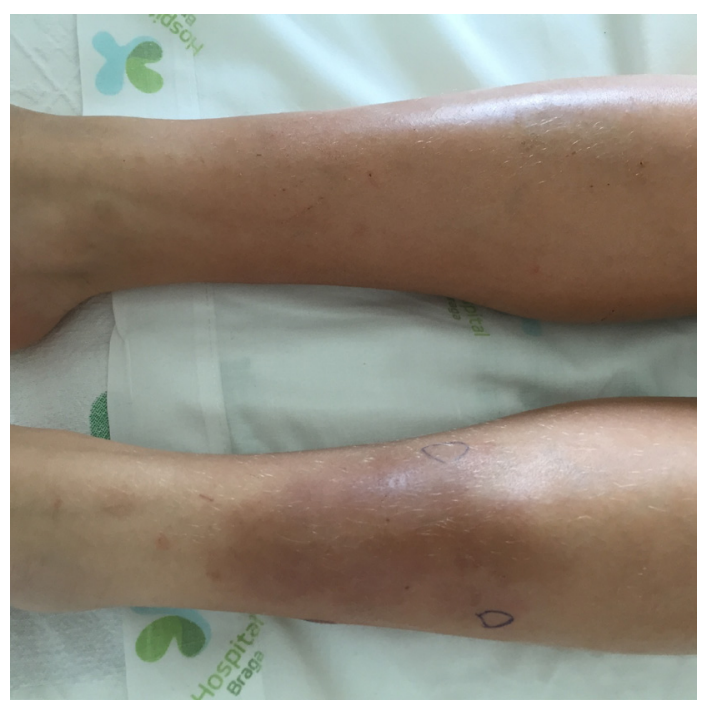

Figure 1 Erythaema, oedema and nodules in the left shin.

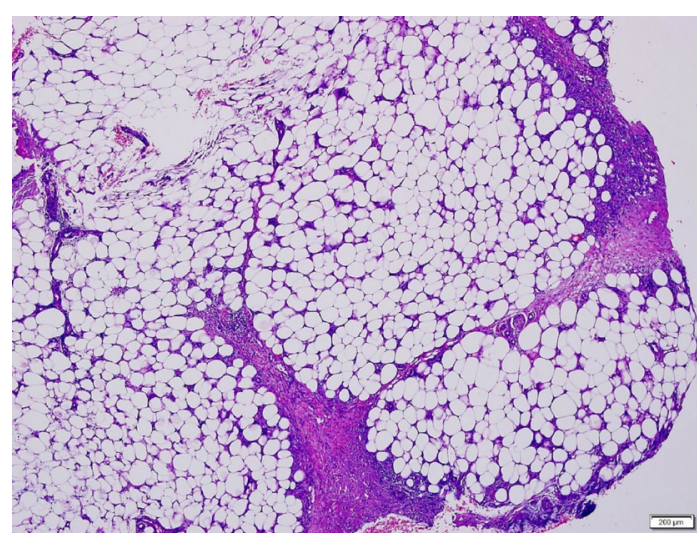

Figure 2 Incisional biopsy. H\&E $\times 40$. Septal panniculitis.

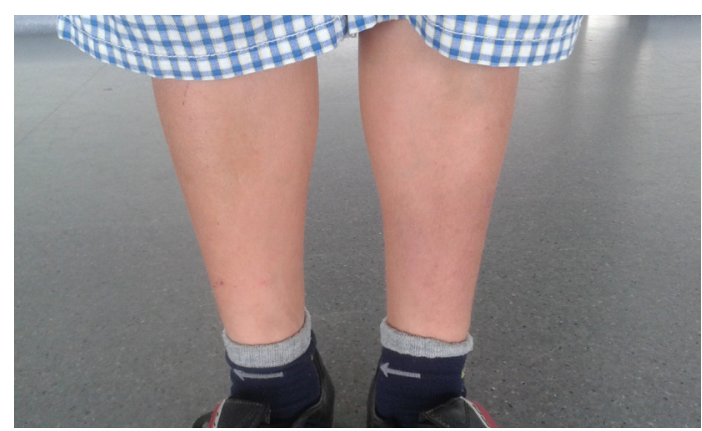

Figure 3 Re-evaluation 4 weeks after discharge.

cause is identifiable, but systemic inflammatory diseases, infectious diseases, neoplasm and drug reactions should be excluded. ${ }^{1}$ The most common provoking insult in children is $\beta$-haemolytic Streptococcus. ${ }^{3}$ Diagnosis is clinical: bilateral erythematous nodules, frequently in the shins, that evolve in the course of 4-8 weeks with complete resolution. ${ }^{1}$ When the diagnostic criteria are not fulfilled, biopsy must be performed to clarify doubtful cases. ${ }^{13}$

\section{Learning points}

- Erythaema nodosum is diagnosed based on clinical criteria: bilateral erythematous nodules, most frequently in the pretibial region.

- When diagnostic criteria are not fulfilled (eg, unilateral lesions), incisional biopsy must be performed for diagnosis.

- Unilateral erythaema nodosum is rare, but one must be aware of this entity. 
Contributors Report written by FCT and overseen by SM.

Competing interests None declared.

Patient consent Guardian consent obtained.

Provenance and peer review Not commissioned; externally peer reviewed.

(c) BMJ Publishing Group Ltd (unless otherwise stated in the text of the article) 2017. All rights reserved. No commercial use is permitted unless otherwise expressly granted.

\section{REFERENCES}

1 Schwartz RA, Nervi SJ. Erythema nodosum: a sign of systemic disease. Am Fam Physician 2007:75:695-700.

2 Litwin L, Machura E. The etiology and clinical manifestation of erythema nodosum in hospitalized children - analysis of 12 cases. Preliminary report. Dev Period Med 2014;18:506-12.

3 Kakourou T, Drosatou P, Psychou F, et al. Erythema nodosum in children: a prospective study. J Am Acad Dermatol 2001:44:17-21

Copyright 2017 BMJ Publishing Group. All rights reserved. For permission to reuse any of this content visit http://group.bmj.com/group/rights-licensing/permissions.

BMJ Case Report Fellows may re-use this article for personal use and teaching without any further permission.

Become a Fellow of BMJ Case Reports today and you can:

- Submit as many cases as you like

- Enjoy fast sympathetic peer review and rapid publication of accepted articles

- Access all the published articles

- Re-use any of the published material for personal use and teaching without further permission

For information on Institutional Fellowships contact consortiasales@bmjgroup.com

Visit casereports.bmj.com for more articles like this and to become a Fellow 